\title{
Immunosuppressive treatment for peripheral neuropathies in Sjogren's syndrome - a systematic review
}

\author{
ANDREEA CAMELIA HUMĂ ${ }^{1}$, EVELYN MARIA KECSKEȘ ${ }^{1}$, DELIA TULBĂ $\breve{ }^{2}$, \\ PAUL BĂLĂNESCU ${ }^{1,3}$, CRISTIAN BĂICUȘ ${ }^{1,3}$ \\ 1 “Carol Davila" University of Medicine and Pharmacy, Faculty of Medicine, Bucharest, Romania \\ ${ }^{2}$ Neurology Department, Colentina Clinical Hospital, Bucharest, Romania \\ ${ }^{3}$ Internal Medicine Department, Colentina Clinical Hospital, Bucharest, Romania
}

\begin{abstract}
Background. Sjogren's syndrome (SS) is among the most frequent autoimmune diseases and one of its most severe extraglandular manifestations is peripheral neuropathy. There is no consensus about peripheral neuropathy treatment in SS. Our aim is to identify studies proving the efficiency of immunosuppressive treatment on peripheral neuropathies in SS.

Methods. The search was conducted on the PubMed (MEDLINE) database. Studies with patients diagnosed with SS and peripheral neuropathy were included. Treatment with one of the following was among inclusion criteria: glucocorticoids (GC), rituximab (RTX), azathioprine (AZA), mycophenolic acid (MMF), cyclophosphamide (CP), methotrexate (MTX), plasmapheresis or iv immunoglobulins (IV IG).

Results. A total of 116 results were found and abstracts were examined. 103 papers were excluded, and the remaining 13 papers were analyzed. They were 3 case series and 10 case reports, retrospective, totalizing 62 patients of which $22(35.5 \%)$ received IV IG, $8(13 \%)$ received RTX, 7 $(11 \%) \mathrm{CP}$, and $5(8 \%)$ received only GC. Drug associations containing corticosteroids were frequent. Of those 22 treated with IV IG, 18 patients improved (82\%), and 4 stabilized (18\%).

IV IG was useful in sensory, motor and sensorimotor neuropathies. CP had good results in mononeuritis multiplex, while autonomic neuropathies responded well to GC or RTX. AZA, RTX, MTX, MMF or plasmapheresis were not used alone. Follow-up periods were heterogenous and the evaluation of the neuropathy was not systematic.

Conclusion. There is only low level evidence (retrospective case reports and case series). In most cases, IV IG treatment in patients with peripheral neuropathies and SS resulted in clinical improvement, while other therapies, such as RTX, corticosteroids and CP proved to be useful in a handful of cases.
\end{abstract}

Key words: systematic review, peripheral neuropathy, Sjogren's syndrome, immunosupression.

\section{INTRODUCTION}

Sjogren's syndrome is an autoimmune disease characterized by glandular symptoms, such as dryness of mouth (xerostomia) and eyes (xeroftalmia). Although its pathogenesis is not completely clear, a focal lymphocytic infiltrate in the exocrine secretory glands seems to be a typical finding [1] Extraglandular involvement is encountered in nearly half of the patients and can affect the liver, lungs, musculoskeletal system, and the central and peripheral nervous system (PNS) [2].

The most frequent neurological manifestation of SS is peripheral neuropathy [3]. The prevalence of peripheral nerve involvement in SS is highly variable between studies, ranging from $2 \%$ to $60 \%$ [4]. Amongst peripheral neuropathies in patients with SS, sensorimotor, sensory axonal neuropathy and small fiber neuropathy seem to be the most common $[4,5]$, although mononeuritis multiplex, sensory neuronopathy and autonomic neuropathy are also encountered [4].

Although PNS manifestations in SS are not uncommon (prevalence ranging from $5 \%$ to $20 \%$ ), there is no consensus regarding their treatment. IV IG, corticosteroids and RTX are among the most frequently reported therapies, with varying degrees of success.

The aim of the present systematic review is to identify suitable treatment options for peripheral neuropathies in SS.

\section{MATERIAL AND METHODS}

The search was performed on the PubMed (MEDLINE) database on $8^{\text {th }}$ March 2018 with the following MeSH search terms: 
For neuropathy: "Peripheral nervous system disease", "polyneuropath", "neuropath", "polyneuritis", "neuritis".

For Sjogren's syndrome the MeSH terms were "Sjogren's syndrome", "sicca syndrome", "xerostomia", "hyposialia".

For treatment, MeSH terms: "immunoglobulins, intravenous", "Rituximab", "mycophenolic acid", "Azathioprine", "Cyclophosphamide", "Plasmapheresis", "Immunosuppressive agents", "corticosteroids".

The entire search algorithm is presented below:

(C(C(()(peripheral nervous system disease [MeSH Terms]) OR neuropath* [Text Word]) OR polyneuropath* [Text Word]) OR neuritis* [Text Word]) OR polyneuritis [Text Word])) AND ((((sjogren's syndrome [MeSH Terms]) OR sicca syndrome [MeSH Terms]) OR xerostomia [MeSH Terms]) OR hypossialia))) AND (((((((rituximab [Text Word]) OR immunoglobulins, intravenous [MeSH Terms]) OR ((mycophenolic acid [MeSH Terms]) OR mofetil [Text Word])) OR ((Azathioprine [MeSH Terms]) OR azathioprine [Text Word])) OR ((Cyclophosphamide [MeSH Terms]) OR cyclophosphamide [Text Word])) OR ((Plasmapheresis [MeSH Terms]) OR plasmapheresis [Text Word])) OR Immunosuppressive agents [MeSH Terms]) OR ((corticosteroids [Text Word] or glucocorticoids [Text Word] OR "Prednisone" [Mesh]) OR "Prednisolone" [Mesh] OR (methyl [All Fields] AND ("prednisolone" [MeSH Terms] OR prednisolone [Text Word]))))

Titles and abstracts were selected, read and screened by ACH. Most of the times, the full-text article was needed in order to make a decision about inclusion. The selection was made according to the criteria below. When needed, consultations with EMK, DT, PB and CB were arranged and a common decision was reached through discussion. Full-text articles were retrieved and analyzed.

Inclusion criteria: We included articles referring to the pathogenic treatment of the neuropathy in patients with SS up to $8^{\text {th }}$ March 2018. Only articles in English were included. As we did not find randomized controlled studies, we included case reports, case series and observational studies. Patients of both genders were included, diagnosed with SS and peripheral neuropathy. The treatment they followed was with one or more of the following: GC, AZA, MMF, CP, RTX, plasmapheresis, MTX or IV IG.

Exclusion criteria: Pediatric patients (under 18-year-olds) were excluded. Among article types, narrative reviews were excluded. Neurologic conditions such as cranial neuropathies, myelitis, optic neuritis, acute inflammatory demyelinating poliradiculoneuropathy (AIDP) and chronic inflammatory demyelinating polyneuropathy (CIDP) were excluded. We excluded also the patients with ganglionopathies because of the different pathogenic mechanism, which could mean different treatment. Patients with cryoglobulinemic neuropathies were excluded for the very same reason. Additionally, articles for which full-text was not found were not included.

\section{RESULTS}

In total, 116 articles were screened from database inception onwards and the abstracts were examined. 92 articles were excluded: 7 narrative reviews, 44 articles referring to other types of neuropathy, neuronopathy, optic neuritis or central nervous system (CNS) involvement, 37 articles which did not refer to neuropathy treatment, 3 articles with POEMS or TRALI syndrome and 1 pediatric case (Figure 1).

The remaining 24 articles were assessed for eligibility and a further 11 articles were excluded. In the end, 13 articles were included in the qualitative synthesis and analyzed by gender, age, clinical, neurophysiologic features, immunosuppressive treatment used and outcome.

The 13 articles analyzed were case reports and case series. The age range of the patients in the studies was 37 to 75 years old at the moment of treatment. One study failed to provide the actual number of males and females [6]. There were 18 women and 13 men and 31 subjects for which the genders were not given, in total 62 patients.

There has been no significant interest in publications over the years (Figure 2). The first publication that deals with treatment for PN in SS dates from 1998, roughly 1-2 publications coming up each year.

\section{Treatment in patients with peripheral neuropathy and SS}

The most commonly used treatment course in the 13 articles was drug associations, mainly a corticosteroid and another immunosuppressant. Nine articles report treatment with IV IG, with varying degrees of success. Four articles report associations of other drugs, in addition to the ones included in our search (marked with $O$ in Tables 1,2). Most of the studies analyzed illustrate treatments in which more therapeutic options are tried until an effective 
one is found. Table 1 summarizes the findings of this systematic review.

\section{Corticosteroids}

In all but one article [7] corticosteroids are used, as stand-alone or in an association. Most of the patients included in this analysis received corticotherapy. Usually, prednisone/prednisolone
(Pred) or methylprednisolone (MEP) were used, sometimes a MEP pulse, followed by oral Pred, the doses being tapered off with time.

For the stand-alone regimens, the results varied. In drug associations, Pred or MEP with or MTX had no effect on symptoms and the neuropathies evolved under treatment with them [8]. However, other associations with corticosteroids had a good outcome, which will be discussed in the following sections.

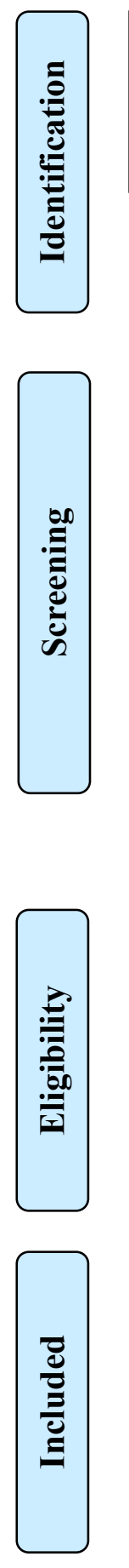

$$
\begin{aligned}
& \text { Records identified through } \\
& \text { database searching } \\
& (\mathrm{n}=116)
\end{aligned}
$$

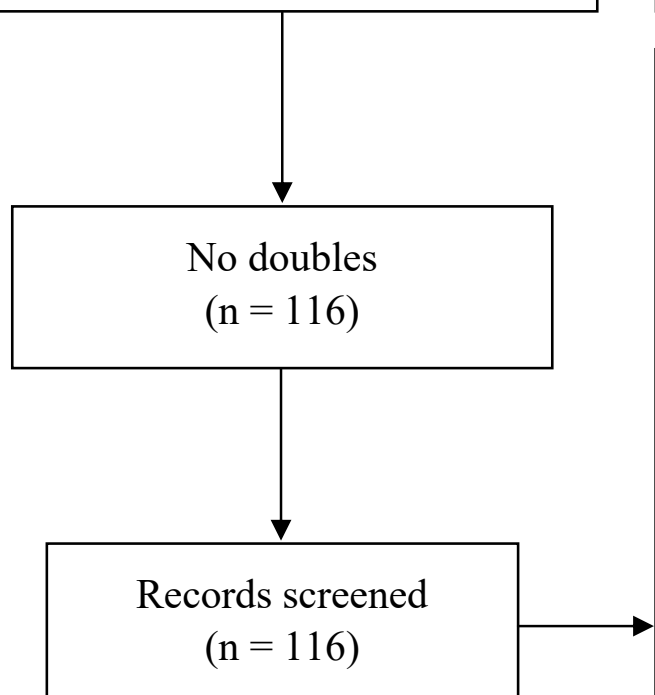

No other databases were used

$$
\begin{aligned}
& \text { Records excluded } \\
& (\mathrm{n}=92)
\end{aligned}
$$

-7 narrative reviews

- 8 optic neuropathy

- 4 neuromyelitis optica spectrum disorder

- 6 neuronopathy

- 4 ganglionopathy

- 4 optic neuritis

- 2 POEMS syndrome

- 10 CNS involvement

- 1 TRALI syndrome

- 8 Cranial nerve involvement

- 37 not referring to SS and neuropathy treatment

- 1 pediatric clinical report

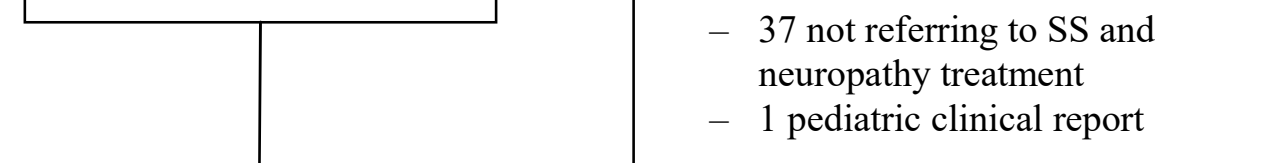

Full-text articles excluded, with reasons

$$
(\mathrm{n}=11)
$$

- 2 articles not found full text

- 1 article in French

- 6 articles in Japanese

- 1 article Hungarian

- 1 pure sensory neuronopathy

Figure 1. Diagram summarizing the selection process. Adapted from [26]. 


\section{Papers discussing treatment in peripheral neuropathy in SS \\ (1969-2018)}

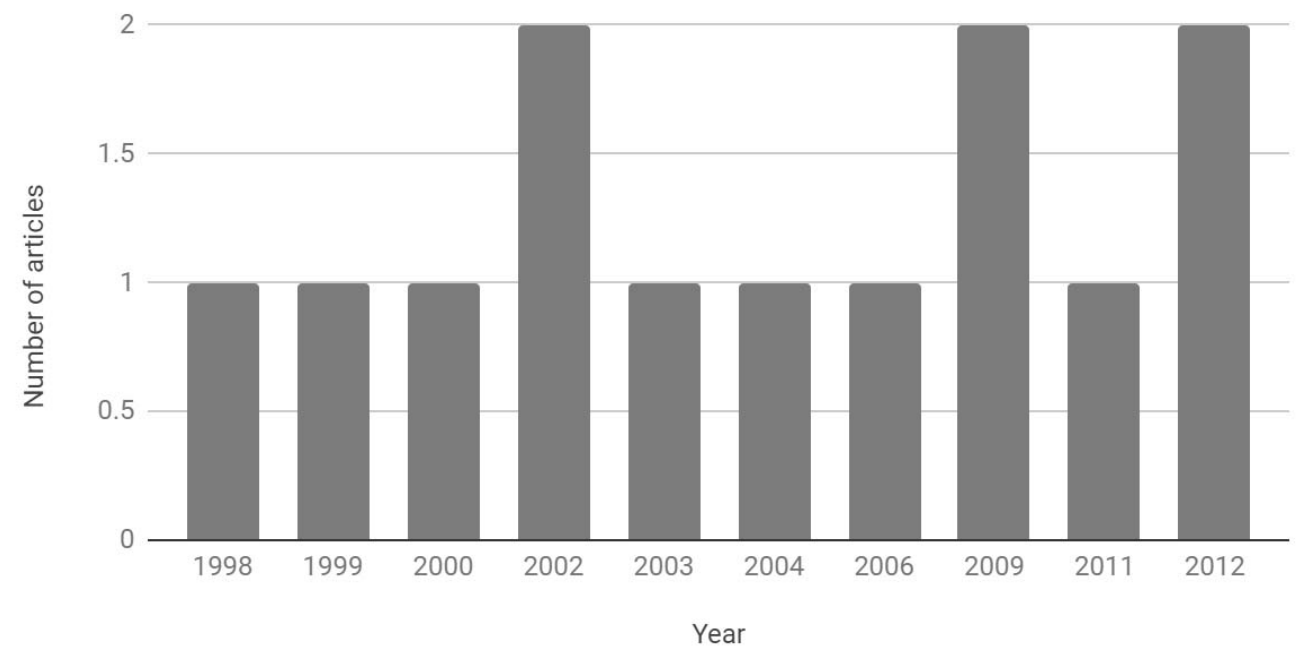

Figure 2. Papers from 1998 to 2012, selected in our systematic review.

\section{Immunoglobulins}

Nine articles used IV IG treatments, alone or in combination with Pred or MEP, with a total of 22 patients receiving this treatment. Changing to IV IG treatment or starting with it was associated most of the times with improvement. Stabilization of symptoms was also seen under this treatment. One study noted that IV IG was successfully used after corticosteroid treatment had failed to bring any improvement [9]. Among drug associations, Pred+IV IG proved to be the most effective out of the Pred combinations [10]. A study showed that patients having treatment with IV IG either improved or stabilized [11]. All patients treated with IV IG in a case report underwent remarkable improvement [7].

\section{Rituximab}

Only two studies with 8 patients included RTX as a treatment option. The first one successfully used RTX and a corticosteroid combination after failed attempts to treat the neuropathy with IV IG and MEP [12]. The second one found that 2 out of 7 patients improved when treated with RTX, in associations with other immunosuppressive agents [13].

\section{Other drugs}

CP and MTX were the other drugs used in our analysis. MTX did not seem to help [8], whereas
CP stabilized the evolution of mononeuritis multiplex [6].

\section{Therapies in different types of neuropathy}

\section{Sensory neuropathy}

In our analysis, 21 patients had sensory neuropathy (Table 2). Eleven patients showed an improved evolution in response to treatment with IV IG, either as a first or second line treatment, associated or not with corticosteroids.

\section{Motor neuropathy}

Only one article focused on motor neuropathy, reporting two patients that underwent immunosuppressive treatment. For both patients, IV IG proved to be beneficial as second line therapy.

\section{Sensorimotor neuropathy}

Patients with sensorimotor neuropathy were frequent in our study, with 30 patients from 5 articles. Pred, IV IG and RTX were effective in this type of neuropathy.

\section{Autonomic neuropathy}

Two patients with autonomic neuropathy were included, each showing improvement with either corticosteroids (MEP, Pred) or RTX. 


\section{Mononeuritis multiplex}

One article reports partial recovery or stabilization in all 7 patients with SS and mononeuritis multiplex when treated with CP monthly, for 6 or 12 months [6].

\section{Follow-up period}

The follow-up summary reveals very uneven follow-up periods, from 1 month to 7 years. Some articles only mention a follow-up minimum [7], while others just give a very broad follow-up interval [8].

When it comes to outcome measurements, the methods used are heterogenous. Only 5 articles used the same methods for neuropathy diagnosis and outcome measurement [12, 8, 14, 15, 13]. Eight studies used clinical evaluation or patient scales for follow-up, the most frequently used being the Visual Analogue Scale (VAS). Three studies used clinical improvement as the only outcome measurement tool $[15,16,17]$, while four articles measure outcomes using clinical evaluation and either VAS or Modified Ranking Scale (MRS) $[12,13,11,18]$.

\section{Comparison between different treatment options}

There were no patients who received treatment with AZA, MMF, MTX, RTX or plasmapheresis alone. These therapeutic means were used in association with other drugs, namely RTX (for MMF, MTX or PE) or glucocorticoids (MTX). The association of MTX and corticotherapy did not prove to be effective.

Of the 62 patients, 22 received treatment with IV IG. Improvement was noticed in 18 patients, who received IV IG either as first line or as a second line treatment, while four patients stabilized under IV IG.

Five patients received solely Pred or Pred+MEP, or MEP, while association of GC with other immunosuppressive therapy was frequent. Of those 5 , in 1 patient the neurological symptoms were stable, 3 improved, while 1 slowly aggravated. Variable results were obtained with combination regimens.

CP was used successfully to stabilize 7 patients with mononeuritis multiplex.

RTX was used for 8 patients and was effective in 3 patients, with better answer to treatment for sensorimotor and sensory neuropathies.

\section{DISCUSSION}

The systematic review we performed offers an insight into the published studies referring to the treatment of peripheral neuropathies in primary Sjogren syndrome. There are a number of points to be made about the published data available at this moment on the topic.

First of all, the only types of articles found through our search were case studies and case series, most studies having one or two patients. The largest study included in our review had 31 patients. No case-control studies or randomized controlled trials were found through our search. Therefore, all the data we present in this study come from small studies and from a total of 62 patients. Another aspect worth mentioning is that extracting patients from larger studies comes with a downfall: patient characteristics are not fully mentioned, gender ratios, age and exact treatment being unknown for some of them. Trying to get in touch with the authors did not prove to be effective.

Secondly, the focus of some of the articles is not specific to our enquiry, with some of the studies reporting on peripheral nervous system involvement in SS and offering limited information on treatment. For instance, one study had as a focus point the treatment in peripheral neuropathies associated with vasculitis and out of the 6 presented cases, only one patient fitted into our search criteria. In another article which described a very complex case, the peripheral neuropathy and its treatment were given very little space [14].

As far as treatment is concerned, it is difficult to draw definite conclusions. The 13 articles selected through our search offered only a qualitative analysis of the question, as a quantitative analysis was not possible in this case. The most frequent treatment choices were IV IG, RTX and GC. Twenty-two patients of the total of 62 were treated with IV IG, and a majority of them responded well to treatment (18 out of $22,81.8 \%$ ). Only $37.5 \%$ of those treated with RTX or RTX associations improved ( 3 out of 8 ), while the outcomes for glucocorticoid treatment are not as straight forward because of the multiple associations in which it is involved.

According to our findings, sensory neuropathy responds well to IV IG, whereas IV IG effect on sensorimotor involvement is variable. It also seems to be beneficial in motor neuropathies. RTX has a good effect on sensorimotor and sensory neuropathies. Autonomic neuropathies respond to either corticosteroids or to IV IG. 
Table 1

Summary of articles included in the systematic review. Ineffective. Improvement. Stabilization/partial recovery

\begin{tabular}{|c|c|c|c|c|c|}
\hline AUTHORS & YEAR & STUDY TYPE & PATIENTS & TREATMENT & OUTCOME \\
\hline M Pertovaara et al. [12] & 2012 & Letter to the Editor & 1 & $\begin{array}{l}\text { IV IG + Pred, MEP + O, } \\
\text { RTX + MEP }\end{array}$ & $\begin{array}{l}\text { IV IG + Pred } M E P+O \\
\text { RTX }+ \text { MEP }\end{array}$ \\
\hline A Mekinian et al. [13] & 2012 & Observational & 7 & $\begin{array}{l}\text { RTX }+ \text { corticosteroids/RTX }+ \\
\text { immunosuppressive agent }^{*}\end{array}$ & $\begin{array}{l}2 / 7 \text { at } 3 \text { months } \\
\text { ( } 1 \text { sensorimotor, } 1 \text { sensory) }\end{array}$ \\
\hline S Rist et al. [11] & 2011 & Observational & 9 & IV IG +/- MEP & $6 / 9,3 / 9$ \\
\hline D Wakasugi et al. [27] & 2009 & Case report & 1 & Pred + O, IV IG & Pred + O IVIG \\
\hline S Morozumi et al. [7] & 2009 & Case series & 5 & IV IG & $5 / 5$ \\
\hline M Kizawa et al. [18] & 2006 & Case report & 1 & IV IG + Pred & IVIG+ Pred \\
\hline S Delalande et al. [6] & 2004 & Observational & 31 & CP; Corticosteroids & CP (7/31); Corticosteroids \\
\hline Y Levy et al. [8] & 2003 & Case report & 1 & $\begin{array}{l}\text { Corticosteroids + MTX, } \\
\text { IV IG + Pred }\end{array}$ & $\begin{array}{l}\text { Corticosteroids }+ \text { MTX IV } \\
\text { IG + Pred }\end{array}$ \\
\hline H Mochizuki et al. [9] & 2002 & Case report & 2 & $\begin{array}{l}\text { MEP Pred, IV IG/ Pred, } \\
\text { IV IG }\end{array}$ & $\begin{array}{l}\text { MEP Pred, } I V I G / \text { Pred, } I V \\
\text { IG }\end{array}$ \\
\hline M Shimoyama et al. [15] & 2002 & Case report & 1 & MEP, Pred & MEP, Pred \\
\hline JK Min et al. [14] & 2000 & Case report & 1 & Pred & Pred \\
\hline JL Dupond et al. [16] & 1999 & Letter to the Editor & 1 & Pred + O, IV IG & Pred $+O, \boldsymbol{I V} \boldsymbol{I G}$ \\
\hline J Pascual et al. [17] & 1998 & Letter to the Editor & 1 & O, Pred, IV IG + Pred, IV IG & O, Pred, IV IG + Pred, IV IG \\
\hline
\end{tabular}

$\mathrm{O}$ - other drugs (antiepileptics/chlorambucil/hydroxychloroquine/fludrocortisone/carbamazepine/amitriptyline/neuroleptics/ mexiletine/ local capsaicin). PE - plasmapheresis. Pred: prednisone [11, 16, 17], prednisolone [12, 27, 18, 9, 15, 14]. ${ }^{*} \mathrm{MMF} / \mathrm{MTX}(2) / \mathrm{AZA} / \mathrm{PE}$.

Table 2

Neuropathy types and treatment Ineffective. Improvement. Stabilization/partial recovery

\begin{tabular}{|c|c|c|c|c|}
\hline AUTHORS & NEUROPATHY TYPE & TREATMENT & OUTCOME & FOLLOW-UP \\
\hline M Pertovaara et al. [12] & $\begin{array}{l}\text { sensorimotor polyneuropathy } \\
(\mathrm{n}=1)\end{array}$ & $\begin{array}{l}\text { IV IG + Pred, MEP + O, } \\
\text { RTX + MEP }\end{array}$ & \begin{tabular}{|l|} 
IV IG + Pred $M E P+$ \\
$O R \boldsymbol{R T X}+\boldsymbol{M E P}$ \\
\end{tabular} & 30 months \\
\hline A Mekinian et al. [13] & $\begin{array}{l}\text { sensory polyneuropathy }(\mathrm{n}=3) \\
\text { sensorimotor polyneuropathy } \\
(\mathrm{n}=4)\end{array}$ & $\begin{array}{l}\text { RTX }+ \text { corticosteroids/RTX }+ \\
\text { immunosuppressive agent }\end{array}$ & $\begin{array}{l}2 / 7 \text { at } 3 \text { months } \\
(1 \text { sensorimotor, } \\
1 \text { sensory }) \\
\end{array}$ & 33 months \\
\hline S Rist et al. [11] & $\begin{array}{l}\text { sensorimotor }(\mathrm{n}=5) \\
\text { sensory non ataxic } \\
\text { polyneuropathy }(\mathrm{n}=4) \\
\end{array}$ & IV IG +/- MEP & $6 / 9,3 / 9$ & 27 months \\
\hline D Wakasugi et al. [27] & sensory polyneuropathy $(\mathrm{n}=1)$ & Pred $+\mathrm{O}$, Pred $+\mathrm{O}+\mathrm{IV}$ IG & Pred + O IV IG & 7 weeks \\
\hline S Morozumi et al. [7] & sensory neuropathy $(\mathrm{n}=5)$ & IV IG & $5 / 5$ & $\begin{array}{l}60 \text { days } \\
\text { minimum }\end{array}$ \\
\hline M Kizawa et al. [18] & sensory neuropathy $(\mathrm{n}=1)$ & IV IG + Pred & IVIG+ Pred & 9 months \\
\hline S Delalande et al. [6] & $\begin{array}{l}\text { sensorimotor polyneuropathy } \\
(\mathrm{n}=19) \text { sensory neuropathy } \\
(\mathrm{n}=5) \\
\text { mononeuritis multiplex }(\mathrm{n}=7)\end{array}$ & $\mathrm{CP}$; Corticosteroids & $\begin{array}{l}\text { CP }(7 / 31) \\
\text { Corticosteroids }\end{array}$ & 7 years \\
\hline Y Levy et al. [8] & sensory neuropathy $(\mathrm{n}=1)$ & \begin{tabular}{|l|} 
Corticosteroids + MTX \\
IV IG + Pred \\
\end{tabular} & \begin{tabular}{|l|} 
Corticosteroids + \\
MTX IV IG + Pred \\
\end{tabular} & $1-5$ years \\
\hline H Mochizuki et al. [9] & motor neuropathy $(\mathrm{n}=2)$ & MEP Pred, IV IG/ Pred, IV IG & $\begin{array}{l}\text { MEP Pred, } \boldsymbol{I} \boldsymbol{V} \boldsymbol{I} \boldsymbol{G} / \\
\text { Pred, IV IG }\end{array}$ & $\begin{array}{l}2 \text { years, } 2 \\
\text { months }\end{array}$ \\
\hline M Shimoyama et al. [15] & autonomic neuropathy $(\mathrm{n}=1)$ & MEP, Pred & MEP, Pred & 7 years \\
\hline JK Min et al. [14] & $\begin{array}{l}\text { sensorimotor polyneuropathy } \\
(\mathrm{n}=1)\end{array}$ & Pred & Pred & 4 months \\
\hline JL Dupond et al. [16] & autonomic neuropathy $(\mathrm{n}=1)$ & Pred $+\mathrm{O}, \mathrm{IV}$ IG & Pred $+O, \boldsymbol{I V} \mathbf{I G}$ & 5 years \\
\hline J Pascual et al. [17] & sensory polyneuropathy $(\mathrm{n}=1)$ & O, Pred, IV IG + Pred, IV IG & $\begin{array}{l}\text { O, Pred, IV IG + Pred, } \\
\text { IV IG }\end{array}$ & 30 months \\
\hline
\end{tabular}

$\mathrm{O}$ - other drugs (antiepileptics/chlorambucil/hydroxychloroquine/fludrocortisone/carbamazepine/amitriptyline/neuroleptics/mexiletine/ local capsaicin). PE - plasmapheresis. Pred: prednisone [11, 16, 17], prednisolone [12, 27, 18, 9, 15, 14]. ${ }^{*} \mathrm{MMF} / \mathrm{MTX}(2) / \mathrm{AZA} / \mathrm{PE}$. 
This is in keeping with the findings of other authors for different neuropathies.

IV IG is used in inflammatory conditions due to their immunomodulatory properties, blocking the $\mathrm{Fc}$ receptors and suppressing cytokines. They have been used favorably in both non-ataxic [19] and ataxic [20] SS neuropathies.

Corticosteroids and IV IG were found to have good results in SS neuropathies in smaller studies [21].

RTX led to improvement in polyneuropathies (sensorimotor, simple or cryoglobulin-related), as shown in a number of studies [22, 23, 24, 25].

Due to the small number of studies included, the outcomes we observed might not be extrapolated on larger patient populations. Therefore, larger multicentric studies on this topic are needed.

The main limitation to our review is the type of articles included (10 case reports and 3 case series, with 62 patients in total). In addition, outcome assessment is done using a lot of different evaluation methods, which makes outcome comparison difficult. Eight articles used either clinical assessment or a subjective scale to assess response to treatment. However, three studies only reported improvement of symptoms, without any quantification. Lastly, no gender or age analysis could be done, given that data regarding these patient characteristics were missing.

\section{CONCLUSIONS}

The findings of our review come from a limited number of studies and patients (10 case reports, 3 case series, 62 patients in total).

The most frequent therapies for SS peripheral neuropathies were IV IG, RTX and corticosteroids. IV IG proved to be a successful treatment option for sensory, motor or sensorimotor neuropathies associated with SS. RTX and GC could be used for a range of different neuropathies. CP had good results for mononeuritis multiplex.

Introducere. Sindromul Sjogren (SS) este printre cele mai frecvente boli autoimune și una dintre cele mai severe manifestări extraglandulare este neuropatia periferică. Nu există un consens pentru tratamentul neuropatiilor periferice din SS. Scopul nostru este să identificăm studii care demonstrează eficacitatea tratamentului imunosupresor in neuropatiile periferice din SS.

Metode. Căutarea a fost efectuată în baza de date PubMed (MEDLINE). Au fost incluse studiile raportând pacienți diagnosticați cu SS și neuropatii periferice. Printre criteriile de includere a fost tratamentul imunosupresor, cu unul dintre: glucocorticoizi (GC), rituximab (RTX), azatioprină (AZA), micofenolat mofetil (MMF), ciclofosfamidă (CP), metotrexat (MTX), imunoglobuline i.v. (IV IG) sau plasmafereză.

Rezultate. In total au fost găsite 116 articole și au fost analizate rezumatele. 103 articole au fost excluse, iar cele 13 articole rămase au fost analizate. Au fost 10 raportări de cazuri și 3 serii de cazuri, retrospective, care au totalizat 62 de pacienți, dintre care 22 (35,5\%) au primit IV IG, 8 (13\%) au primit RTX, 7 (11\%) $C P$ și 5 (8\%) au primit doar corticoterapie. Asocierile medicamentoase cu GC au fost frecvente. IV IG au fost utile în neuropatiile senzoriale, motorii și senzorimotorii. Dintre cei 22 pacienți tratați cu IV IG, 18 au avut un răspuns bun (82\%), iar 4 au rămas stabili (18\%). CP a avut rezultate bune pentru mononeuritis multiplex, iar neuropatiile autonome au răspuns bine la GC sau RTX. Perioadele de urmărire au fost eterogene, iar evaluarea neuropatiei nu a fost sistematică.

Concluzii. Există doar studii cu validitate redusă (cazuri și serii de cazuri retrospective). In cele mai multe cazuri, tratamentul cu IV IG pentru neuropatiile periferice din SS a fost eficient, în vreme ce alte terapii au fost utile într-un număr de cazuri.

Correspondence to: Andreea Camelia Humă, "Carol Davila” University of Medicine and Pharmacy, Faculty of Medicine, Bucharest, Romania

E-mail: andreea.c.huma@gmail.com

Conflict of interest disclosure: The authors declare there is no conflict of interest. 


\section{REFERENCES}

1. FISHER B.A., BROWN R.M., BOWMAN S.J., BARONE F. A review of salivary gland histopathology in primary Sjögren's syndrome with a focus on its potential as a clinical trials biomarker. Ann Rheum Dis. 2015; 74:1645-50.

2. CHERIF E., BOUKHRIS I., HAJJI R., HASSINE LB., AZZABI S., KECHAOU I. et al. Extra-glandular manifestations of primary Sjögren's syndrome. Eur J Intern Med. 2013; 24:e119.

3. ATTWOOD W., POSER CM. Neurologic complications of Sjogren's syndrome. Neurology. 1961; 11:1034-41.

4. PAVLAKIS P.P., ALEXOPOUlOS H., KOSMIDIS M.L., MAMALI I., MOUTSOPOUlOS H.M., TZIOUFAS A.G. et al. Peripheral neuropathies in Sjögren's syndrome: A critical update on clinical features and pathogenetic mechanisms. J Autoimmun. 2012; 39:27-33.

5. MARGARETTEN M. Neurological manifestations of primary Sjögren's syndrome. Reumatologia. 2018; 56:99-105.

6. DElalande S., DE SEZE J., FAUCHAIS A.-L., HACHULlA E., STOJKOVIC T., FERRIBY D. et al. Neurologic manifestations in primary Sjögren syndrome. Medicine (Baltimore). 2004; 83:280-91.

7. MOROZUMI S., KAWAGASHIRA Y., IIJIMA M., KOIKE H., HATTORI N., KATSUNO M. et al. Intravenous immunoglobulin treatment for painful sensory neuropathy associated with Sjögren's syndrome. J Neurol Sci. 2009; $279: 57-61$.

8. LEVY Y., UZIEL Y., ZANDMAN G.G., AMITAL H., SHERER Y., LANGEVITZ P. et al. Intravenous immunoglobulins in peripheral neuropathy associated with vasculitis. Ann Rheum Dis. 2003; 62:1221-3.

9. MOCHIZUKI H., KAMAKURA K., MASAKI T., HIRATA A., NAKAMURA R., MOTOYOSHI K. Motor dominant neuropathy in Sjoegren's syndrome: Report of two cases. Intern Med. 2008; 41:142-6.

10. FONT J., RAMOS-CASALS M., DE LA RED G., POU A., CASANOVA A., GARCIA-CARRASCO M. et al. Pure sensory neuropathy in primary Sjögren's syndrome. Longterm prospective followup and review of the literature. J Rheumatol. 2003; 30:1552-7.

11. RIST S., SEllaM J., HACHUlla E., SORDET C., PUECHAL X., HATRON P. et al. Experience of intravenous immunoglobulin therapy in neuropathy associated with primary Sjögren's syndrome: A national multicentric retrospective study. Arthritis Care Res (Hoboken). 2011; 63:1339-44.

12. PERTOVAARA M., KORPELA M. Sustained response to rituximab in a patient with Sjögren's syndrome and severe refractory polyneuropathy. Clin Exp Rheumatol. 2012; 30:808.

13. MEKINIAN A., RAVAUD P., HATRON P.Y., LARROCHE C., LEONE J., GOMBERT B. et al. Efficacy of rituximab in primary Sjogren's syndrome with peripheral nervous system involvement: results from the AIR registry. Ann Rheum Dis. 2012; 71:84-7.

14. MIN J.K., PARK K.S., YU W.J., LEE Y.S., PARK S.M., PARK S.H. et al. Systemic mononuclear inflammatory vasculopathy associated with Sjögren's syndrome in a patient with primary biliary cirrhosis. Korean J Intern Med. 2000; 15:89-92.

15. SHIMOYAMA M., OHTAHARA A., OKAMURA T., WATANABE M., FUJIMOTO Y., TESHIMA S. et al. Isolated autonomic cardiovascular neuropathy in a patient with primary Sjögren syndrome: a case of successful treatment with glucocorticoid. Am J Med Sci. 2002; 324:170-2.

16. DUPOND J.L., GIL H., DE WAZIERES B. Five-year efficacy of intravenous gammaglobulin to treat dysautonomia in Sjögren's syndrome. Am J Med. 1999; 106:125.

17. PASCUAL J., CID C., BERCIANO J. High-dose i.v. immunoglobulin for peripheral neuropathy associated with Sjögren's syndrome. Neurology. 1998; 51:650-1.

18. KIZAWA M., MORI K., IIJIMA M., KOIKE H., HATTORI N., SOBUE G. Intravenous immunoglobulin treatment in painful sensory neuropathy without sensory ataxia associated with Sjögren's syndrome. J Neurol Neurosurg Psychiatry. 2006; 77:967-9.

19. MOLINA J.A., BENITO-LEÓN J., BERMEJO F., JIMÉNEZ-JIMÉNEZ F.J., OLIVÁN J. Intravenous immunoglobulin therapy in sensory neuropathy associated with Sjögren's syndrome. J Neurol Neurosurg Psychiatry. 1996; 60:699.

20. TAKAHASHI Y., TAKATA T., HOSHINO M., SAKURAI M., KANAZAWA I. Benefit of IVIG for long-standing ataxic sensory neuronopathy with Sjögren's syndrome. IV immunoglobulin. Neurology. 2003; 60:503-5.

21. MORI K., IIJIMA M., KOIKE H., HATTORI N., TANAKA F., WATANABE H. et al. The wide spectrum of clinical manifestations in Sjögren's syndrome-associated neuropathy. Brain. 2005; 128:2518-34.

22. GORSON K.C., NATARAJAN N., ROPPER A.H., WEINSTEIN R. Rituximab treatment in patients with IVIg-dependent immune polyneuropathy: A prospective pilot trial. Muscle Nerve. 2007; 35:66-9.

23. BOTEZ S.A., HERRMANN D.N. Prolonged remission of a demyelinating neuropathy in a patient with lymphoma and Sjögren's syndrome after Rituximab therapy. J Clin Neuromuscul Dis. 2010; 11:127-31.

24. MEIJER J.M., MEINERS P.M., VISSINK A., SPIJKERVET F.K.L., ABDULAHAD W., KAMMINGA N. et al. Effectiveness of rituximab treatment in primary Sjögren's syndrome: A randomized, double-blind, placebo-controlled trial. Arthritis Rheum. 2010; 62:960-8.

25. VOULGARELIS M., GIANNOULI S., TZIOUFAS A.G., MOUTSOPOULOS H.M. Long term remission of Sjogren's syndrome associated aggressive $B$ cell non-Hodgkin's lymphomas following combined $B$ cell depletion therapy and CHOP (cyclophosphamide, doxorubicin, vincristine, prednisone). Ann Rheum Dis. 2006; 65:1033-7.

26. MOHER D., LIBERATI A., TETZLAFF J., ALTMAN D.G., GROUP T.P. Preferred reporting items for systematic reviews and meta-analyses: The PRISMA Statement. PLoS Med. 2009; 6:e1000097.

27. WAKASUGI D., KATO T., GONO T., ITO E., NODERA H., KAWAGUCHI Y. et al. Extreme efficacy of intravenous immunoglobulin therapy for severe burning pain in a patient with small fiber neuropathy associated with primary Sjögren's syndrome. Mod Rheumatol. 2009; 19:437-40.

Received August $1^{\text {st }} 2019$ 